\title{
Behavioral Geography: an Ecoliteracy Perspective and Critical Thinking Skills in Men and Women
}

\author{
Nadiroh Nadiroh, Uswatun Hasanah and Vania Zulfa \\ Universitas Negeri Jakarta, Indonesia
}

Received: 2018-10-20 Accepted: 2019-05-29

\author{
Keywords: \\ Crime rate; \\ Gini index; \\ school dropout; \\ panel data; \\ partial autocorrelation
}

Corespondent Email: nadiroh@unj.ac.id

\begin{abstract}
This study aims at explaining the behavior of students of the biology-Jakarta State University study program on environmental preservation in the perspective of ecoliteracy and critical thinking skills. Ecoliteracy is an understanding and behavior or the action of a person towards the environment. The results of the study show that there is no effect of the interaction between ecoliteracy and thinking Skills. In addition, there is also no interaction between ecoliteracy and gender. This study supports previous relevant research and provides new empirical information that ecoliteracy and critical thinking skills are the causes of someone contributing to preserving the environment. However, the influence of ecoliteracy interactions and critical thinking skills is not significant. In addition, the interaction in the ecoliteracy and gender perspective needs to be ignored because both of them make the same contribution. Therefore, the application of ecoliteracy must begin early. The application of ecoliteracy can also be integrated into the media that are currently developing rapidly. So that at the university level, the concept of ecoliteracy has emerged in a more creative and innovative form by initiating new innovations in the more advanced environment.
\end{abstract}

(9) 2019 by the authors. Licensee Indonesian Journal of Geography, Indonesia.

This article is an open access article distributed under the terms and conditions of the Creative Commons

Attribution(CC BY NC) licensehttps://creativecommons.org/licenses/by-nc/4.0

\section{Introduction}

The environment is one of the most important elements of planet Earth. Therefore, the environment has a special role in the survival of all living things on earth. Environmental quality certainly affects the quality of the creatures that live in it. Therefore, it is very important for us to understand the importance of the environment for the survival of life on earth.

Today, the environment that has the largest natural resources in which at the same time a place to depend on various living things is forested. But unfortunately, the majority of forests in Indonesia have begun to erode due to human actions that cut down trees in the forest without thinking of the impact that will occur afterward (Habibullah, 2018; Siburian, 2016; Wegscheider et al., 2018). In the past few decades, forest management and utilization in Indonesia has failed in realizing sustainable forests. Forest Watch Indonesia (2009) research found that in 60 years Indonesia's forest area had decreased from the original 162 million ha to only 88,17 million ha or had a shrinkage of around 46.3 percent (Hajar \& Waluyo, 2017; Purba, 2014). If the conditions are allowed to continue, then the forests in Indonesia can experience extinction.

Another environmental problem is household waste that is not properly treated, this can cause pollution and even flood natural disasters. In addition, the increasing number of motorized vehicles causes increasing air pollution (Kurniawati, 2017; Listyarini, Tarumingkeng, Fauzi, \& Hutagaol, 2017; Muslihudin \& Amrullah,
2017). These problems are tangible forms of problems caused by human actions that reflect their ignorance of the environment and the lack of sufficient knowledge in managing and preserving the environment (Kumurur, 2012). Previous research also shows that the beginning of the extinction of human interaction with nature. This illustrates the importance of awareness in maintaining the environment of the people who are still lacking. This awareness is called Fritjof Capra as ecoliteracy (Schimek, 2016). Ecoliteracy or ecological intelligence is the Skills of a person to adapt to the ecological domain or place of residence (Lees, 2017). A person's ecological intelligence is based on knowledge, attitudes, and behaviors that are in harmony with the natural environment. As explained by Supriatna that ecological intelligence is complex. This intelligence is supported by cognitive, affective (social and emotional), and psychomotor elements (Etmagusti, 2010). The desire to protect the environment is based on knowledge about the environment. Awareness to save a damaged environment is based on affective aspects. While actions to preserve the environment describe the psychomotor aspects.

Thus, the real action is needed to develop ecoliteracy from the education sector. Departing from a small matter, students are miniatures of society and university life can be represented as a miniature country. In the world of education in universities, 
students act as agents of change and relay milestones in the continuation of future lives. Students are expected to have sufficient knowledge, in this case, knowledge in managing and preserving the environment so as to foster an understanding of the importance of contributing to preserving the environment.

One of the environmental problems in Indonesia is overcome by the education strategy, namely the implementation of Environmental Population Education (PKLH) in various educational institutions (Lees, 2017). Jakarta State University (UNJ) is the forerunner of the organizer of Population and Environmental Education (PKLH) at the higher education level (Saribas, Teksoz, \& Ertepinar, 2014)

Planting the concept of environmental education in UNJ since 1991 is certainly based on the hope that students have a high sensitivity and concern for the surrounding environment, both the campus environment and the environment in which they live. The fact that there is Population and Environment Education as a course is still not enough to have a real impact on the campus environment. Therefore, it requires revitalization and support from various parties to integrate PKLH in all subjects and in each learning.

A person's understanding of the environment (ecoliteracy) alone is not enough to shape a person's behavior to preserve the environment. Other supporting factors are needed. According to Richard Khan, critical pedagogy can be one way to make the ecoliteracy movement a better direction (Livesey \& Intili, 1996). A person who thinks critically will process his knowledge and influence his behavior, in this case contributing to environmental preservation. The Skills to think critically can affect one's perspective and mindset in acting and judging something (Poston \& Bouvier, 2010). Critical thinking is reflective and plausible thinking that is focused on determining what is further believed and done (Larsen, Randy J.; Buss, David M.; Wismeijer, Andreas; Song, John; van den Berg, 2017). The Skills to think critically and the ecoliteracy of students towards contributions to environmental preservation can be a benchmark for achieving environmental education courses at Jakarta State University. This can also be a consideration for making policies on the importance of environmental education courses so that they will be held in each study program. Critical thinking can lead to the formation of a wise nature. Critical thinking allows one to analyze information carefully and make the right decisions.

In the realm of cognitive psychology, it is stated that each individual behavior begins with a deep thought process. In this case the Skills to think critically. Critical thinking is an intellectual process that aims to synthesize, analyze, conceptualize, apply, and evaluate information collected or generated from a communication, reasoning, reflection, experience, observation to guide actions and beliefs (Arnold \& Wade, 2015). Critical thinking is the Skills to think in a reflective and reasoned way that relies on making decisions that must be done and believed (Scriven \& Paul, 1987). Critical Thinking Skills also involves five dimensions, namely (1) giving a simple explanation, (2) building basic skills, (3) concluding, (4) providing further explanations, and (5) managing strategies and tactics (Ennis, 2011). Critical thinkers train cognitive skills in seeking information, estimating, analyzing, giving logical reasons, distinguishing, applying standards, and changing knowledge (Muhfahroyin, 2010).

In addition, this study also looks at the influence of gender on the contribution of environmental preservation. Gender is an internal factor that influences the sensitivity of each individual to the problems around (Desfandi \& Maryani, 2017). In social life, gender includes a role in the social construction of a society that is not determined by sex, therefore every man and woman must have the same rights in social life. But physical differences make people think that men have a higher degree in the social life of society, whereas the rights of men and women in social life are actually the same (Ford, 2015; Robinson \& Richardson, 2015).

With the existence of ecoliteracy or understanding of the environment, it can be seen whether within students, both men and women, who have the Skills to think critically contribute to environmental preservation. If the student has an environmentally caring attitude, it is hoped that it will give good results to the contribution of environmental preservation.

Based on the background and the relevant research above, it can be seen that ecoliteracy and critical thinking skills have the power to influence one's actions. Higher education institutions, in this case, universities, are the right research locations to see the potential of students as agents of change to contribute to applying sustainable knowledge that has been obtained in everyday life. There are no studies that look at the effects of ecoliteracy and critical thinking skills on environmental conservation contributions. Therefore, this research is very important to do to see the impact of ecoliteracy at the university level so that further relevant policies can be made in order to create sustainable environmental preservation.

\section{The Methods}

This research use quantitative research paradigm by using survey technique. The location of study is in Jakarta State University, Jakarta on March 2018. Respondent/data source of this study are students of biology education study program. Data Collection is done through questionnaire and ecoliteracy test. Instrument of study is developed based on previous ecoliteracy research by Roth (Disinger, John F; Roth, 1992). Component and indicator of Adiwiyata school which is issued by Ministry of Environmental Affairs and measurement instrument of ecoliteracy is developed 


\begin{tabular}{llcc}
\hline \multicolumn{3}{c}{ Table 1. Research Design } \\
\hline \multicolumn{3}{c}{ Ecoliteracy (A) } \\
\hline \multicolumn{3}{c}{ High (A1) } & Low (A2) \\
Critical & High (B1) & $(\mathrm{A} 1, \mathrm{~B} 1)$ & $(\mathrm{A} 2, \mathrm{~B} 1)$ \\
Thingking & Low (B2) & $(\mathrm{A} 1, \mathrm{~B} 2)$ & $(\mathrm{A} 2, \mathrm{~B} 2)$ \\
Skills (B) & & & $(\mathrm{A} \mathrm{X} \mathrm{B)}$ \\
Interaction & & & \\
\hline
\end{tabular}

based on core competence of ecoliteracy which is issued by The Center for Ecoliteracy (Desfandi \& Maryani, 2017; Schimek, 2016). Variables which are observed in this study are ecoliteracy (X1), critical thinking skills (X2), contribution on environmental conservation (Y), and gender as other variable. Research design such as

Hypotheses were tested using two-ways analysis of variance (ANOVA). The mechanism of test is done by comparing significance value of calculation result with significance value (probSkills) of 0.05 . The decision taken use criteria "if calculation significance value is < 0.05 ; then $\mathrm{H} 0$ is rejected", and "if calculation significance value is $>0.05$; then $\mathrm{H} 0$ is accepted." Hypothesis test is done by IBM SPSS 17 software.

\section{Result and Discussion}

Based on the calculation with two-ways ANOVA, it can be explained the results of hypotheses test in Table 2.

Differences in the Contribution of Environmental Conservation between Students with High Ecoliteracy (A1) and Low Ecoliteracy (A2).

The results of the first hypothesis testing based on the results of analysis of variance (Two-Way ANOVA) obtained that the value of Sig. $=0.024$ which has a smaller value than the value of $\alpha=0.05$ or $\mathrm{F}$ count $=$ 5.555 which is greater than the value of Ftable $=4.11$, then $\mathrm{H} 1$ is accepted. Thus overall there are significant differences in environmental preservation contributions between students who have high ecoliteracy (A1) and low ecoliteracy (A2).

The findings in this study state that there are differences in the average score of environmental preservation contributions between groups of students who have high ecoliteracy and low ecoliteracy. Students who have high ecoliteracy get higher average scores than students who have low ecoliteracy. Someone who is ecologically educated means that someone has the Skills to make the right decisions and take actions to solve environmental problems (Schimek, 2016).

References to environmental literacy in environmental education literature tend not to pay special attention to the fundamental debate about literacy (Stables, 1998; Stables \& Bishop, 2001). Therefore, in this article, the researcher limits the ecoliteracy of nominal, functional, and operational ecoliteracy as follows: (1) Nominal; demonstrate the Skills to recognize many basic terms used in communicating about the environment and provide a rough definition of work, as well as their meanings, (2) Functional; show broader knowledge and understanding of the nature and interaction between human social systems and other natural systems, and (3) Operational; demonstrate progress beyond functional literacy both in the breadth and depth of understanding and skills in environmental problems (Disinger, John F.; Roth, 1992).

Viewed from three levels, namely nominal, functional, and operational, it can be seen that the nominal dimension which has the highest frequency is 48 respondents followed by the functional dimension of 31 respondents and the operational dimension of 21 respondents. The frequency of respondents in the ecoliteracy dimension can be seen in Figure 1.

Based on the dimensions of ecoliteracy, the dimensions that have the highest score are nominal. This is because 48 respondents stated that they understood the basic terms and definitions related to environmental preservation. While dimensions that have the lowest score are operational dimensions. This is because less than $25 \%$ of respondents do not have an in-depth understanding of the application of environmental preservation in their daily lives. These 21 respondents also did not yet have special skills related to environmental preservation. This caused the operational dimension to have the lowest score compared to the other two dimensions.

The high score of nominal dimensions, especially students' understanding of basic environmental terms, proves that environmental education given in lectures is inherent and understood by students. Students already have environmental knowledge as evidenced by a high environmental preservation score. The Environmental Education course proved to be beneficial for students. This is supported by the highest value obtained in the ecoliteracy instrument, which is 85 .

Ecological understanding or ecoliteracy is the Skills of a person to read the world system objectively with head, heart, hands, and soul (Sivek \& Hungerford, 1990). This contemplative pedagogy can foster the Skills to make and make the right decisions to contribute to environmental preservation. In addition, this pedagogy is also useful in the process of making decisions and actions in solving environmental problems.

Ecological literacy is also an understanding of the principles of organizations that sustain life. This not only takes into account one's knowledge about the environment but also the attitudes and behavior of that person towards the environment. People like this have an understanding of ecological topics and have the desire to solve problems that have been caused by humans on this planet (Schimek, 2016).

Someone who has high ecoliteracy is already at a high level so that he regularly evaluates the impact and takes actions aimed at maintaining or improving a healthy environment. Such people demonstrate a strong and sustained sense of investment and responsibility 
Indonesian Journal of Geography, Vol. 51 No. 2, August 2019: 114 - 122

Table 2. Summary of Results of Two Path Variance Analysis

(Variable Ecoliteracy and Critical Thinking Skills)

\begin{tabular}{lrrrrr}
\hline \multicolumn{1}{c}{ Source } & Type III Sum of Squares & df & Mean Square & F & Sig. \\
Corrected Model & $1789.200 \mathrm{a}$ & 3 & 599.400 & 6.994 & .001 \\
\hline Intercept & 190164.100 & 1 & 205062.400 & 2392.638 & .000 \\
Ecoliteracy & 435.600 & 1 & 476.100 & 5.555 & .024 \\
Critical & 1020.100 & 1 & 1299.600 & 15.164 & .000 \\
Thinking Skills & & & & & \\
Ecoliteracy & 22.500 & 1 & 22.500 & .263 & .612 \\
Critical & & & & & \\
Thinking Skills & & & & & \\
Error & 3085.400 & 36 & 85.706 & & \\
Total & 209946.000 & 40 & & & \\
\hline
\end{tabular}

a. R Squared $=, 368$ (Adjusted R Squared $=, 316$ )

Source : primary data processing

\section{Level of Critical Thinking Skills}

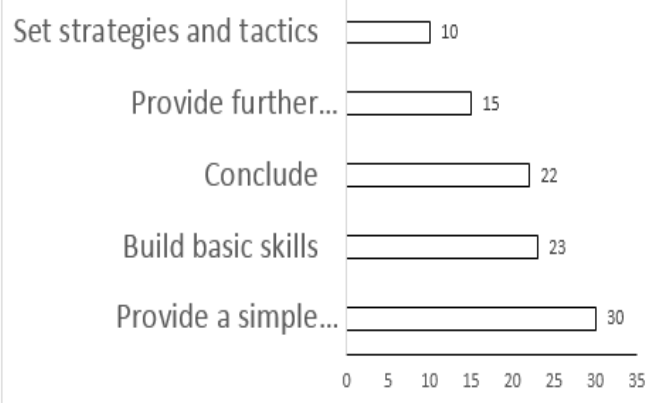

Figure 1. Comparison of the Frequency of Respondents in the Ecoliteracy Dimension

to prevent or restore environmental degradation both personally and collectively and are likely to act at several levels from local to global in doing so (Lees, 2017). The habitual characteristics of environmental literacy are ingrained. They are routinely involved in dealing with the world in general. Student contributions and the development of ecoliteracy must be supported by the awareness of each individual, both in the form of daily experience and in the form of knowledge (Etmagusti, 2010).

Students with high ecoliteracy produce high environmental contributions too. Because in their daily lives they have applied the ecoliteracy in every aspect of life. Someone with high ecoliteracy can also contribute to their concern for the environment because contributions relate to self-confidence. When a person is convinced of the knowledge of the environment he has, he will act according to his knowledge (Saribas et al., 2014). Therefore, the quality of environmental education in the program of each study program must be improved, especially at the Jakarta State University.
Differences in Environmental Conservation Contributions between Students Who Have High Critical Thinking Skills (B1) and Low Kitis Thinking Skills (B2).

The results of testing the second hypothesis based on the results of analysis of variance (Two-Way ANOVA) obtained that the value of Sig. $=0,000$ which is smaller than the value of $\alpha=0.05$ or Fcount $=15.164$ which is greater than the value of Ftable $=4.11$, then $\mathrm{H} 1$ is accepted. Thus overall there are differences in the contribution of significant environmental preservation between students who have high critical thinking skills (B1) and low critical thinking skills (B2).

The findings in this study state that there are differences in the average score of environmental preservation contributions between groups of students who have high critical thinking skills and low critical thinking skills. Students who have high critical thinking skills get higher average scores compared to students who have low critical thinking skills.

There are 5 dimensions to the critical thinking Skills variable (Ennis, 2011). The five dimensions are (1) provide a simple explanation, (2) build basic skills, (3) conclude, (4) provide further explanations, and (5) set strategies and tactics. Based on these five dimensions, it can be seen that the first dimension, namely giving a simple explanation, has the highest frequency of 30 respondents, followed by the second, namely basic skills of 223 respondents, while the dimensions which have the lowest score are the fifth dimension, namely governing strategy and tactics. The frequency of respondents in the dimensions of critical thinking skills can be seen in Figure 2.

Based on the dimensions of critical thinking Skills, the dimension that has the highest score is to provide a simple explanation. This is because 30 respondents can provide simple explanations regarding problems and environmental preservation. While the dimensions that have the lowest score are dimensions 


\section{Level of Critical Thinking Skills}

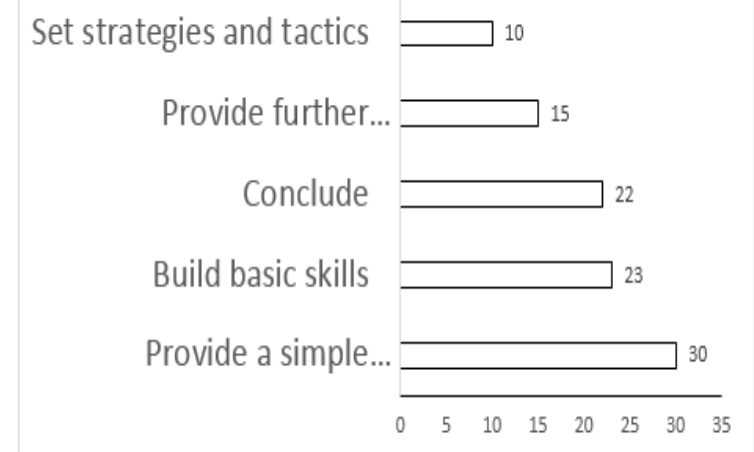

Figure 2. Comparison of the Frequency of Respondents in the Dimensions of Critical Thinking Skills

governing strategy and tactics. This is because only $10 \%$ of respondents have strategies and tactics in environmental preservation. This is the key answer to the main problems in this study. Environmental Education that has been given for many years in Jakarta State University has not had the impact of action or action. Students have high knowledge, high critical thinking skills, but not accompanied by concrete actions in preserving the environment, in this case, the campus environment. Therefore, it is still found in the garbage that is not in place, dirty lecture halls, and halls that leave a lot of garbage after lectures.

The low score of the strategy and tactics dimensions should be overcome in various ways. One of them is by familiarizing activities in the form of real work such as community service that is scheduled regularly. Applied environmental education courses can also be planned to trigger students to be able to apply the knowledge gained in formal lectures in the classroom. This is very important to follow up considering that critical thinking skills are one of the main capital to create students with character.

Recent developments in technology have made critical thinking rest on 21 st-century educational goals. This goal changes the role of educators from transferring information to prepare students to be able to process information by carrying out critical assessments and creative thinking (Carrier, 2009). Another factor that causes the sharpness of critical thinking skills is creativity. Using the equation modeling structure shows that critical thinking skills and creativity meet on one common factor, and are also two separate factors. This shows that the two models have the best fit index, thus confirming the independence of each cognitive component in reference to critical thinking and creativity (Petek \& Bedir, 2018). Whereas in secondary education, other factors that can influence the improvement of learning in environmental education include, (1) learning centered on students, (2) positive relationships between students, (3) positive relationships between teachers and students, and (4) developing and strengthen class rules (Mukminan, 2018).

The background of a critical thinker may not have to be a good decision maker but is expected to be able to utilize extraordinary critical thinking skills in making complex judgments or perspectives. Relevant research is carried out in the health sector in Malaysia, showing that age, gender, ethnicity, education level, and work experience factors significantly impact critical thinking skills.

Age and work experience that significantly impact clinical decision making. Pearson correlation analysis shows a strong and positive relationship between critical thinking skills and decision making. The conclusion of this small-scale study shows that there is a relationship between critical thinking dispositions and clinical decision making in a hospital (Ludin, 2018).

Through a meta-analysis test, the literature synthesis is conducted on critical thinking skills and the success of students to higher education. After systematically searching for relevant literature through electronic databases using search terms, it was found that critical thinking skills were quite related to the success of students entering college. This relationship is constant; however, the level of critical thinking of students is more closely related to long-term results compared to those who are shorter. The meta-regression results show some evidence that the effects are weaker for male and minority college students. Therefore it is very important to foster critical thinking skills for all college students (Ludin, 2018).

Students' critical thinking skills can still be improved. The relevant article summarizes empirical evidence about the impact of teaching on the development and improvement of critical thinking skills, disposition, and student achievement. The results show that there are effective strategies for teaching critical thinking skills at all levels of education and in all fields of disciplines. One of them is providing opportunities for dialogue, exposure of students to authentic problems and examples, and continued mentoring of critical thinking skills (Abrami et al., 2015; Edwards, 2018).

One of the Meta-analysis studies synthesizes research on the advantages of critical thinking skills and attitude disposition over various time frames in college. The results show that both critical thinking skills and dispositions increase substantially compared to the normal college experience. In addition, analysis of curriculum efforts to enhance critical thinking shows that they do not only produce additional longterm benefits. This research has shown that higher education is effective in fostering critical thinking, which can support the pursuit of other educational goals (Huber \& Kuncel, 2016; Utriainen, Marttunen, Kallio, \& Tynjälä, 2017). 
Effect of Interactions between Ecoliteracy and Critical Thinking Skills to Contribute to Environmental Conservation.

The results of the fifth hypothesis testing based on the results of analysis of variance (Two-Way ANOVA) obtained that the value of Sig. $=0.612$ which has a greater value than the value of $\alpha=0.05$ or Fcount $=0.263$ which is smaller than the value of Ftable $=4.11$, then $\mathrm{H} 1$ is rejected. Thus there is an insignificant interaction effect between ecoliteracy and critical thinking skills on environmental conservation contributions. Thus, there is a non-significant interaction effect between ecoliteracy and critical thinking skills on environmental conservation contributions.

The findings in the study found that ecoliteracy and critical thinking abilities influence the contribution of environmental preservation but cannot jointly influence the level of environmental conservation contributions. Based on the environmental behavior model adapted by Vaske, 2001 from the Hines, et. al. (1986/1987) states that a person in action is influenced by various factors (Vaske \& Kobrin, 2001). Both ecoliteracy (knowledge of environmental issues) and critical thinking Skills (education) have an influence on the contribution of environmental preservation (responsible environmental behavior), but both come from two different poles. Ecoliteracy is at level 2 as general environmental variables. While critical thinking skills are at level 1 as sociodemography (sociodemographic). Ecoliteracy directly influences a person's behavior, whereas critical thinking Skills will influence the level of thought and understanding first so that it ultimately affects behavior.

There are three components of human psychology that are related to nature, namely cognitive, affective, and behavior (Vaske \& Kobrin, 2001). The cognitive component is a situation where there is a sense of connection or sense of connection between humans and nature. Affective component is a situation where there is a relationship of mutual maintenance of the response (caring response) between humans and nature. While the component of behavior (behavioral) is a situation where there is a pattern that is applied to always show its commitment to an activity. A sense of "connectedness" can encourage a feeling to preserve nature and then sustainably encourage a commitment to protect nature (Arriaga \& Agnew, 2001).

These three variables influence each other, but it is proven in this study that ecoliteracy and critical thinking abilities cannot jointly influence the contribution of preserving one's environment. Ecoliteracy and critical thinking Skills are tendencies that can shape attitudes and behavior. With the establishment of a good understanding of the environment (ecoliteracy) in this case the learning of environmental education is carried out on biology education students, Jakarta State University, it will have an impact on the behavior of good conservation contributions to the environment of the Jakarta State University. Therefore, good environmental education courses are applied in other study programs so that they can have a significant impact on the environmental sustainSkills of Jakarta State University.

Based on other relevant research, it is stated that education awareness can also affect the level of knowledge of students, especially in the development of sustainable schools. In this study conducted in Malaysia, researchers developed a model of education awareness. The results obtained to support this study, that ecoliteration can be formed early and have a significant

\section{Estimated Marginal Means of Contribution on Environmental Conservation}

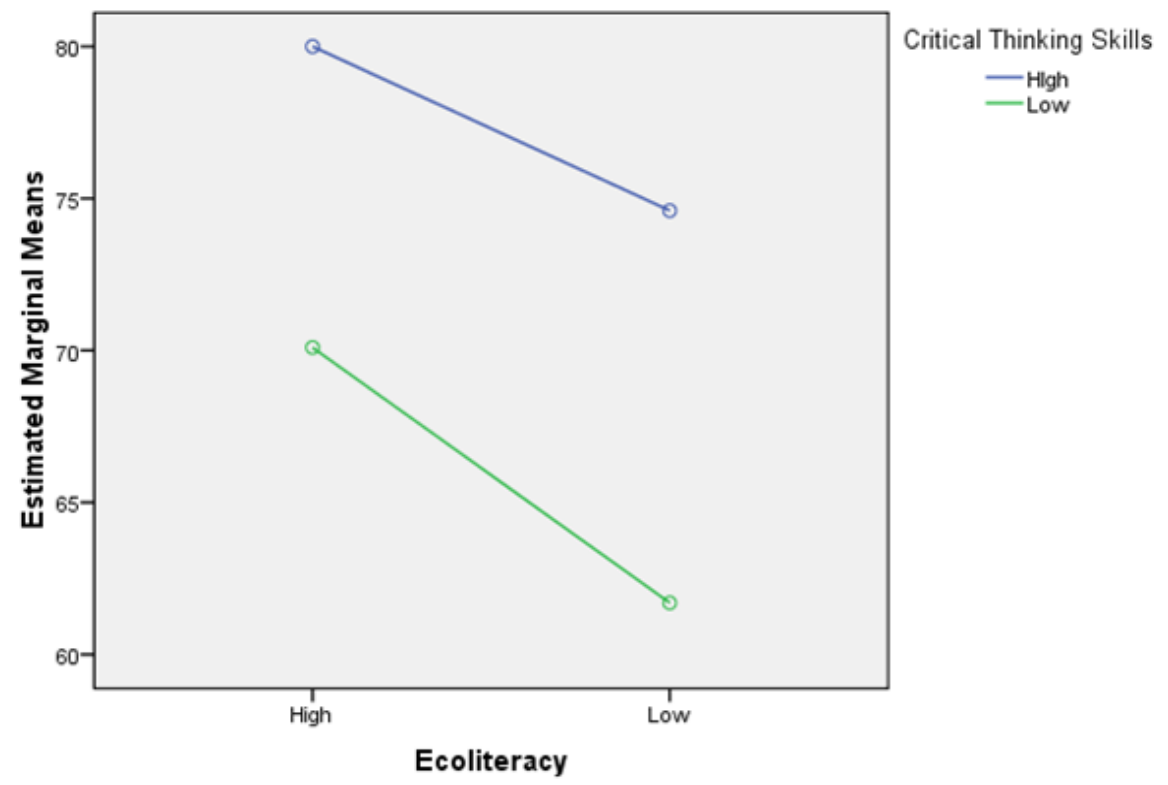

Figure 3. Profil Plots Interaction Between Ecoliteracy and Critical Thinking Skills toward Contribution on Environmental Conservation 
impact on the formation of student knowledge, in this case, the formation of critical thinking skills (Mahat, Saleh, Hashim, \& Nayan, 2016).

\section{Effect of the Interaction between Ecoliteracy and Gender}

In the calculation of two-way ANAVA Sig. > 0.05, which is $0.06>0.05$, meaning that the null hypothesis (Ho) is accepted and $\mathrm{H} 1$ is rejected. This means that there is no difference in the average score of environmental conservation contributions between male and female student groups. In this study, the average contribution of male environmental preservation was 78.80 and the average environmental contribution of women was 77.60. Based on these results, there were no significant differences in the mean scores of the two groups.

According to Poston, gender shows differences that occur in men and women not from a biological perspective (sex) but in terms of social life (Larsen, Randy J.; Buss, David M.; Wismeijer, Andreas; Song, John; van den Berg, 2017). Gender is defined as a rule or norm of behavior related to gender in a social system of society, because of that gender is often identified with sex or sex, even though both have different concepts (Wienanda et al., 2017). Therefore there is no significant difference. Both men and women have good environmental preservation scores.

Other research shows that men and women have no difference in the level of knowledge in this case ecoliteracy. Comparisons between men and women show that girls tend to reach higher levels of reasoning and more coherent reasoning skills, but the difference is not statistically significant. Because formal education institutions such as schools seem to only have very
Table 3. Summary of Results of Two Path Variance Analysis (Variables of Ecoliteracy and Gender)

\begin{tabular}{rrrr}
\hline Source & df & F & Sig. \\
\hline Ecoliteracy & 1 & 8.065 & .003 \\
Gender & 1 & 9.598 & .006 \\
Ecoliteracy & 1 & 3.610 & .860 \\
${ }^{\star}$ Gender & & & \\
\hline
\end{tabular}

little role in developing student reasoning both male and female (Isdaryanti, Rachman, Sukestiyarno, Florentinus, \& Widodo, 2018). The achievements of girls may be related to independence, maturity, and maturity of thinking. These three things do not show a very significant influence as a differentiator of the level of male and female reasoning (Widodo, Waldrip, \& Herawati, 2016).

\section{Conclusion}

From this study, it can be concluded that ecoliteracy and the Skills to think critically cause someone to contribute to the preservation of the environment. However, the effect of ecoliteracy and critical thinking skills is not significant. Besides it, in the perspective of men and women ecoliteracy needs to be ignored because both of them make the same contribution.

\section{Acknowledgement}

The author would like to thanks to all biology education students who become data sources in this study.

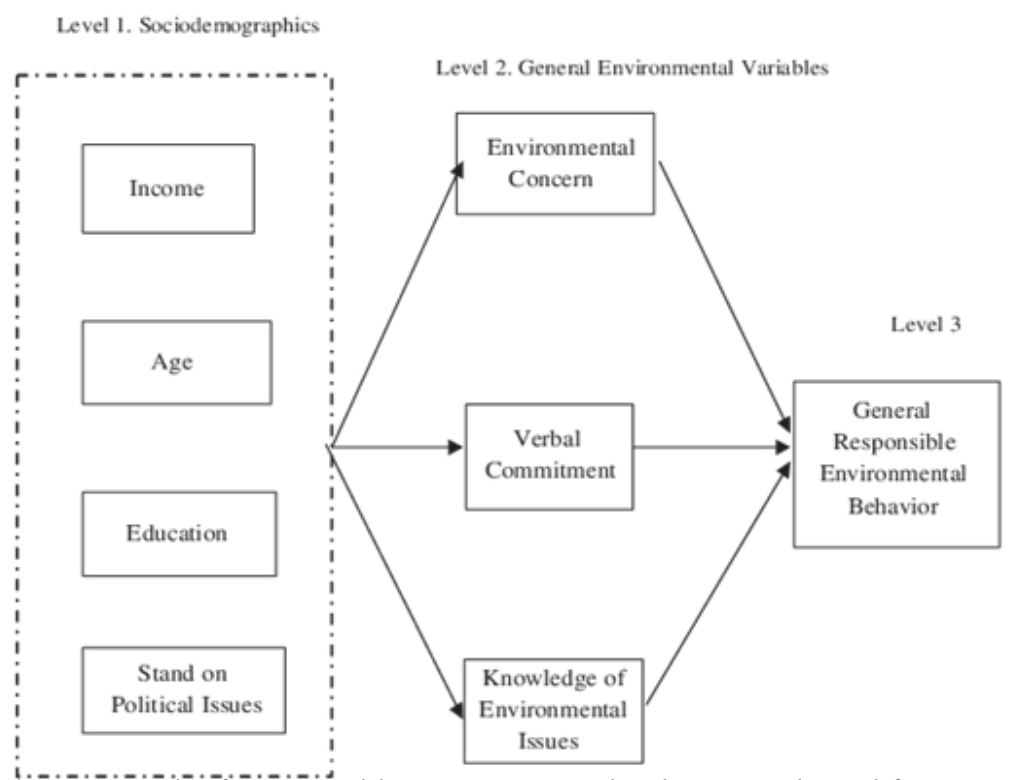

Figure 4. Conceptual Framework of Responsible Environmental Behavior. Adapted from Hines, Hungerford, and Tomera (1987) (Restall \& Conrad, 2015); Hungerford and Volk (1990) (Hines, Hungerford, \& Tomera, 1987); and Sivek and Hungerford (1989/1990) (Knapp, Volk, \& Hungerford, 1997) 


\section{References}

Abrami, P. C., Bernard, R. M., Borokhovski, E., Waddington, D. I., Wade, C. A., \& Persson, T. (2015). Strategies for teaching students to think critically: A meta-analysis. Review of Educational Research, 85(2), 275-314.

Arnold, R. D., \& Wade, J. P. (2015). A definition of systems thinking: a systems approach. Procedia Computer Science, 44, 669-678.

Arriaga, X. B., \& Agnew, C. R. (2001). Being committed: Affective, cognitive, and conative components of relationship commitment. Personality and Social Psychology Bulletin, 27(9), 1190-1203. https://doi. org/10.1177/0146167201279011

Carrier, S. J. (2009). Environmental Education in the Schoolyard: Learning Styles and Gender. The Journal of Environmental Education, 40(3), 2-12. https://doi. org/10.3200/JOEE.40.3.2-12

Desfandi, M., \& Maryani, E. (2017). Building Ecoliteracy Through Adiwiyata Program (Study at Adiwiyata School in Banda Aceh). Indonesian Journal of Geography, 49(1), 51.

Disinger, John F.; Roth, C. E. (1992). Environmental Literacy. ERIC/CSMEE Digest. Colombus. https://doi. org/10.1641/0006-3568(2000)050[0916:EL]2.0.CO;2

Edwards, L. C. (2018). The Craft of Infusing Critical Thinking Skills: A Mixed-Method Research on Implementation and Student Outcome. Journal on Centers for Teaching and Learning, 9, 47-72.

Ennis, R. H. (2011). The nature of critical thinking: An outline of critical thinking dispositions and abilities. In Sixth International Conference on Thinking, Cambridge, MA.

Etmagusti, P. L. Y. S. (2010). Efektivitas Ekoliterasi Dalam Meningkatkan Pengetahuan Pengetahuan, Sikap, dan Perilaku Masyarakat Mengenai Education For Sustainable Development Berbasis Tanaman Pangan Lokal, 1-13.

Ford, L. (2015). Sustainable development goals: all you need to know. The Guardian, 19.

Habibullah, H. (2018). Konsep dan Kebijakan Restorasi Sosial di Indonesia. Sosio Informa, 4(1).

Hajar, I., \& Waluyo, T. J. (2017). Peran Center for Internasional Forestry Research (Cifor) Di Indonesia Terkait Mekanisme Reducing Emission From Deforestation and Forest Degradation (REDD) 2007-2014. Jurnal Online Mahasiswa (JOM) Bidang Ilmu Sosial Dan Ilmu Politik, 4(1), 1-10.

Hines, J. M., Hungerford, H. R., \& Tomera, A. N. (1987) Analysis and Synthesis of Research on Responsible Environmental Behavior: A Meta-Analysis. The Journal of Environmental Education, 18(2), 1-8. https://doi.org/ 10.1080/00958964.1987.9943482

Huber, C. R., \& Kuncel, N. R. (2016). Does college teach critical thinking? A meta-analysis. Review of Educational Research, 86(2), 431-468.

Isdaryanti, B., Rachman, M., Sukestiyarno, Y. L., Florentinus, T. S., \& Widodo, W. (2018). Teachers' performance in science learning management integrated with character education. Jurnal Pendidikan IPA Indonesia, 7(1), 9-15. https://doi.org/10.15294/jpii.v7i1.12887

Knapp, D., Volk, T. L., \& Hungerford, H. R. (1997). The Identification of Empirically Derived Goals for Program Development in Environmental Interpretation. The Journal of Environmental Education, 28(3), 24-34. https://doi.org/10.1080/00958964.1997.9942826
Kumurur, V. (2012). Pengetahuan, Sikap Dan Kepedulian Mahasiswa Pascasarjana Ilmu Lingkungan Terhadap Lingkungan Hidup Kota Jakarta. Ekoton, 8(2), 1-24.

Kurniawati, I. D. (2017). Indikator Pencemaran Udara Berdasarkan Jumlah Kendaraan dan Kondisi Iklim (Studi di Wilayah Terminal Mangkang dan Terminal Penggaron Semarang). Universitas Muhammadiyah Semarang.

Larsen, Randy J.; Buss, David M.; Wismeijer, Andreas; Song, John; van den Berg, S. M. (2017). Personality psychology: Domains of knowledge about human nature" (2nd ed.). New York: McGraw-Hill Education.

Lees, M. (2017). Effect of Contemplative Pedagogy on the Ecoliteracy of Undergraduate Public State University Students. ProQuest Dissertations and Theses, 210. Retrieved from http://libproxy.library. wmich.edu/login?url=https://search.proquest.com/ docview/1930653061 ?accountid=15099\%0Ahttp:// primo-pmtna0 1.hosted.exlibrisgroup.com/ openurl/01 WMU/01 WMU_SERVICES??url_ ver=Z39.88-2004\&rft_val_fmt=info:ofi/ fmt:kev:mtx:dissertation\&genr

Listyarini, S., Tarumingkeng, R. C., Fauzi, A., \& Hutagaol, P. (2017). Estimasi Nilai Penurunan Kesehatan Akibat Polusi Gas NOx di Udara DKI Jakarta. Jurnal Matematika, Sains, Dan Teknologi, 8(2), 109-125.

Livesey, D. J., \& Intili, D. (1996). A Gender Difference in Visual-Spatial Ability in 4-Year-Old Children: Effects on Performance of a Kinesthetic Acuity Task. Journal of Experimental Child Psychology, 63(2), 436-446. https:// doi.org/https://doi.org/10.1006/jecp.1996.0057

Ludin, S. M. (2018). Does good critical thinking equal effective decision-making among critical care nurses? A crosssectional survey. Intensive and Critical Care Nursing, 44, 1-10. https://doi.org/https://doi.org/10.1016/j. iccn.2017.06.002

Mahat, H., Saleh, Y., Hashim, M., \& Nayan, N. (2016). Model Development on Awareness of Education for Sustainable Schools Development in Malaysia. Indonesian Journal of Geography, 48(1), 37. https://doi.org/10.22146/ijg.12446

Muhfahroyin, M. (2010). Memberdayakan Kemampuan Berpikir Kritis Siswa Melalui Pembelajaran Konstruktivistik. Jurnal Pendidikan Dan Pembelajaran (JPP), 16(1), 88-93.

Mukminan. (2018). Dimensions and Factors of Contemporary Geography Learning Climate at Senior High School. Indonesian Journal of Geography, 50(1), 78-86. https:// doi.org/http://dx.doi.org/10.22146/ijg.34567

Muslihudin, M., \& Amrullah, M. (2017). Model Dss Untuk Mengetahui Tingkat Bahaya Asap Kendaraan Menggunakan Metode Fuzzy Multiple Attribute Decision Making (FMADM). Jurnal TAM (Technology Acceptance Model), 6, 9-14.

Poston, D. L., \& Bouvier, L. F. (2010). An Introduction to Demography. Cambridge: Cambridge University Press.

Purba, C. P. P. Potret keadaan hutan Indonesia: periode 20092013 (2014). Forest Watch Indonesia.

Restall, B., \& Conrad, E. (2015). A literature review of connectedness to nature and its potential for environmental management. Journal of Environmental Management, 159(June), 264-278. https://doi. org/10.1016/j.jenvman.2015.05.022

Robinson, V., \& Richardson, D. (2015). Introducing gender and women's studies. London: Macmillan International Higher Education. 
Saribas, D., Teksoz, G., \&Ertepinar, H. (2014). The Relationship between Environmental Literacy and Self-efficacy Beliefs toward Environmental Education. Procedia - Social and Behavioral Sciences, 116, 3664-3668. https:/doi.org/ https://doi.org/10.1016/j.sbspro.2014.01.820

Schimek, M. J. (2016). How an Experience in Nature Affects Ecoliteracy of High School Students. Hamline University.

Scriven, M., \& Paul, R. (1987). Critical thinking as defined by the National Council for Excellence in Critical Thinking. In 8th Annual International Conference on Critical Thinking and Education Reform, Rohnert Park, CA (pp. 25-30).

Siburian, R. (2016). Kehidupan Masyarakat Sekitar Hutan dan Ketahanan Sosial pada Ekologi Hutan yang Berubah. Jurnal Masyarakat Dan Budaya, 18(3), 467-486.

Sivek, D. J., \& Hungerford, H. (1990). Predictors of Responsible Behavior in Members of Three Wisconsin Conservation Organizations. The Journal of Environmental Education, 21(2), 35-40. https://doi.org/10.1080/00958964.1990.99 41929

Stables, A. (1998). Environmental literacy: Functional, cultural, critical. The case of the SCAA guidelines. Environmental Education Research, 4(2), 155-164.
Stables,A., \&Bishop, K. (2001). WeakandStrongConceptions of Environmental Literacy: Implications for environmental education. Environmental Education Research, 7(1), 8997. https://doi.org/10.1080/13504620125643

Utriainen, J., Marttunen, M., Kallio, E., \& Tynjälä, P. (2017). University applicants' critical thinking skills: The case of the Finnish educational sciences. Scandinavian Journal of Educational Research, 61(6), 629-649.

Vaske, J. J., \& Kobrin, K. C. (2001). Place Attachment and Environmentally Responsible Behavior. The Journal of Environmental Education, 32(4), 16-21. https://doi. org/10.1080/00958960109598658

Wegscheider, S., Purwanto, J., Margono, B. A., Nugroho, S., Buchholz, G., \& Sugardiman, R. A. (2018). Current Achievements to Reduce Deforestation in Kalimantan, 50(2), 109-120.

Widodo, A., Waldrip, B., \& Herawati, D. (2016). Students argumentation in science lessons: A story of two research projects. Jurnal Pendidikan IPA Indonesia, 5(2), 199208. https://doi.org/10.15294/jpii.v5i2.5949

Wienanda, W. K., Widiati, U., Mada, U. G., Malang, U. N., Tunggal, C., \& Sleman, D. (2017). Students, Gender, Anxiety, and Speaking. 